\title{
Autobiography as Criticism, Criticism as Autobiography
}

"Okay, okay, okay, we get it: you stutter and so, irredeemably selfconscious, you're devoted to yourself as a subject, also as a symbolic subject, even as some sort of featured player in a collage movie. Don't you finally want to get outside yourself? Isn't that finally what this has to be about, getting beyond the blahblahblah of your endless-" Yes, yes, a thousand times yes. Or, rather, yes and no. I want to get past myself, of course I do, but the only way I know how to do this is to ride along on my own nerve endings; the only way out is deeper in; the only portraits I'm really interested in are self-portraits as well. I'm just trying to be honest here.

I'm drawn to writers who appear to have Heisenberg's Uncertainty Principle tattooed across their forehead: the perceiver by his very presence changes the nature of what's being perceived. In the Afterword to Lolita, Nabokov mentions "a newspaper story about an ape in the Jardin des Plantes which, after months of coaxing by a scientist, produced the first drawing ever charcoaled by an animal; this sketch showed the bars of the poor creature's cage."

I admire Hilton Als's The Women, W.G. Sebald's The Emigrants, and V.S. Naipaul's A Way in the World-books in which the chapters, considered singly, are relatively straightforwardly biographical, but read as a whole and tilted at just the right angle, refract brilliant, harsh light back upon the author. "I only know an object in so far as I know myself and my own determination through it," Hegel says, "for whatever I am is also an object of my consciousness, and I am not just this, that or the other, but only what I know myself to be. I know my object, and I know myself; the two are inseparable."

What Ilove: the critical intelligence in the imaginative position-D.H. Lawrence, Studies in Classic American Literature; Wayne Koestenbaum, The Queen's Throat; Nicholson Baker, U \& I; Geoff Dyer, Out of Sheer Rage, Terry Castle, "My Heroin Christmas"; Anne Carson, Eros the Bittersweet; Albert Goldbarth, Griffin; Richard Stern's "orderly miscellanies"; Roland Barthes, S/Z; Nabokov, Gogol; Beckett, Proust; Proust, all; William James, Varieties of Religious Experience. Sister 
Mary Ignatius, in other words, explaining it all for you-les belles dames sans merci: Joan Didion, all the essays; Elizabeth Hardwick, Sleepless Nights; Pauline Kael, all; Renata Adler, pretty much everything. So, too, on another track: Sandra Bernhard, Without You I'm Nothing; Sarah Silverman, Jesus Is Magic. Then the train going in the opposite direction: Chris Rock, Bring the Pain; Denis Leary, No Cure for Cancer; Rick Reynolds, Only the Truth Is Funny; Larry David, Curb Your Enthusiasm; Spalding Gray, nearly everything; Art Spiegelman, Maus; Ross McElwee, all.

"Criticism demands of the critic a terrible nakedness; a real critic has no one but himself to depend on. He can never forget that all he has to go by, finally, is his own response, the self that makes and is made up of such responses, and yet he must regard that self as no more than the instrument through which the work of art is seen, so that the work of art will seem everything to him and his own self nothing."

-Randall Jerrell

"The crucial art of the essay lies in its perpetrator's masterful control over his own self-exposure. We may at times be embarrassed by him, but we should never feel embarrassed for him. He must be the ringmaster of his self-display. He may choose to bare more than he can bear (that is where the terror comes in), but he must do the choosing, and we must feel that he is doing it. There is a moment in every love affair when the participants risk everything by revealing themselves to each other-a moment of decisive self-revelation, when one person, yielding up her weakest point, exposes her jugular (as wolves do, in surrender), and the other meets the challenge by accepting the offered knowledge and perhaps giving up something in return. All great autobiographical essays contain such moments, moments at which we are made the recipients of information so threatening to the author's integrity, so revealing of her own sense of her weaknesses, that we could destroy her if we misused it. She depends on our love (or, if that is insufficient, then on our distance) to protect her."

-Wendy Lesser 
My impulse is always to read form as content, style as meaning; to push the book toward abstraction, toward doubleness, toward seventeen types of ambiguity. The book is always, in some sense, stutteringly, about its own language. I'm always framing myself and the author as the lone founts of dark wisdom; I'm always the exponent of airy despair; I never touch ground. "Metaphysical" is big. In my formulation, the subject of the book is never what it appears to be. I frequently say that the book is seen to be about $\mathrm{X}$ when really it's about Y. I always read the book as an allegory, as a disguised philosophical argument. "Existence" is frequently mentioned, as are "animal," "sex," "fuck," and "violence." I love the words "powerfully" and "enormously" and "relentlessly" and "bottomlessly." I use "investigation" and "exploration" and "excavation" and "examination" and "rigorous" over and over. What would I do without "meditation"? There's always an implied love story between me and the writer-me loving the book, loving the writer. "Candor" is key-being willing to say what no one else is willing to say. The act of writing is inevitably viewed as an act of courage ("brave" is all over the place). Life's difficult, maybe even a drag; language is (slim) solace. No one else gets what you're doing; I alone get it. You and me, babe. "Intimacy." "Urgency." We alone get life. Let me explain your book-the "text"-to yourself. Let me tell you what your book is about. Life is shit. We are shit. This, alone, will save us-this communication. 